\title{
The Enterprise Web
}

The Enterprise Web is a bureauwide approach to managing U.S. Geological Survey (USGS) information on the Web. Under the direction of the USGS Geographic Information Office, the Enterprise Web operates the Bureau's Web servers and their associated sites. Through a network of people and resources, the Enterprise Web or "E-Web" works with programs and partners to effectively use the USGS Web presence to advance and deliver natural science information. It provides the corporate infrastructure, best practices, and tools to focus the Bureau's Web presence on customer and business needs and to ensure that USGS Web sites are reliable, secure, and in compliance with all applicable laws, Office of Management and Budget (OMB) requirements, and Department of the Interior (DOI) policy.

\section{Goal}

The goal of E-Web is to bring together the USGS community to guide the USGS Web of the Future and establish best practices for customers, partners, and the public to find, get, and use the science information and products of the USGS.

\section{Objectives}

To ensure that customers have access to the information they need from USGS Web sites and pages, E-Web is committed to meeting the following objectives:

- Manage an Enterprise approach for USGS science information on the Web

- Establish and implement policy and governance for the USGS Web presence

- Host and maintain a network of mirrored, failure-resistant servers through the USGS National Web Server System (NatWeb)

- Provide a common look and navigation design for all USGS Web sites

- Develop and monitor security plans and procedures to achieve and maintain Certification and Accreditation (C\&A) of Web infrastructure

- Work collaboratively to enhance the organization and presentation of USGS science information

- Assist USGS programs in managing data and information effectively throughout the product life cycle
- Promote a content management approach to the information product life cycle

- Track and evaluate the performance and use of USGS Web sites

\section{Projects}

Projects currently underway through E-Web that will achieve these objectives include:

- Update, test usability, and maintain support for the USGS home page and its associated Web pages that form the "corporate" suite of information for the Bureau (www.usgs. gov)

- Complete the process of C\&A of all the Bureau's Web servers by July 31,2004

- Develop a bureauwide information architecture model for organizing and presenting scientific and functional information

- Develop a USGS Web customer profile

- Develop and test design standards and templates to provide a common look and navigation design for all USGS Web sites, based on established usability practices

- Develop tools and procedures for automated content approval, review, update, and removal of Web content as part of a content management strategy

- Promote consolidation of USGS Web servers and provide mirrored, failure-resistant management through NatWeb

- Develop and enhance online information resources to enhance information discovery, such as:

- Frequently Asked Questions http://interactive2.usgs. gov/faq/

- USGS Enterprise Web Thesaurus http://ibrary.usgs. gov/eweb_thes.html

- A to Z Index http://answers.usgs.gov/AtoZIndex.htm

- Publications Warehouse http://infotrek.er.usgs.gov/ pubs

- Online Customer Service Center http://www.usgs. gov/ask/index.html 
- Search http://search.usgs.gov/

- Provide assistance to science programs on a case-by-case basis

\section{Collaboration}

The following groups and approaches help to ensure that $\mathrm{E}-\mathrm{Web}$ is a collaborative process that engages people across the Bureau and coordinates with the DOI:

The Enterprise Web Team-Technical and content experts responsible for day-to-day implementation

The USGS Web Advisory Group-Program representatives and managers who provide feedback and recommendations on developing and managing the USGS Web presence to advance science and its delivery

USGS Forums - Special sessions with senior USGS leadership as needed to develop the vision for the USGS Web of the Future and to provide direction for the Web Advisory Group

DOI Web Council-Technical and communication representatives from the Bureaus share information and provide recommendations to the DOI Chief Information Officer on the DOI Web presence.

\section{Contact Information}

For more information about Enterprise Web activities, contact Karen Klima, USGS Enterprise Web Manager, by phone (703-648-6844 or 703-648-6821) or email (kklima@usgs.gov).

"The Internet has provided us with a powerful communication tool that has an incredible return on the investment that the public makes to support the USGS and its science...

The USGS Home Page (www.usgs.gov) is an exciting doorway to real-time information on earthquakes and river flows, maps, publications, databases, software applications, scientific models, and just plain "cool stuff" about the world around you, as well as your federal source for science about the Earth, its natural and living resources, natural hazards and the environment." (Chip Groat, USGS Director, March 3, 2004) 